\title{
THE
}

\section{Experiencing Research Firsthand: The "unClassroom" Experiential Learning Approach to Teaching Research Methods in an LIS Master's Program}

\author{
Lauren $\mathrm{H}$. Mandel \\ University of Rhode Island, lauren_mandel@uri.edu
}

Follow this and additional works at: https://digitalcommons.uri.edu/lsc_facpubs

The University of Rhode Island Faculty have made this article openly available.

Please let us know how Open Access to this research benefits you.

This is a pre-publication author manuscript of the final, published article.

Terms of Use

This article is made available under the terms and conditions applicable towards Open Access

Policy Articles, as set forth in our Terms of Use.

\section{Citation/Publisher Attribution}

Mandel, Lauren H.. "Experiencing Research Firsthand: The "unClassroom" Experiential Learning Approach to Teaching Research Methods in an LIS Master's Program." Journal of Education for Library and Information Science, vol. 58, no. 4, 2017, pp. 187-201. http://dx.doi.org/10.3138/jelis.58.4.187 Available at: http://dx.doi.org/10.3138/jelis.58.4.187

This Article is brought to you for free and open access by the Graduate School of Library and Information Studies at DigitalCommons@URI. It has been accepted for inclusion in Graduate School of Library and Information Studies Faculty Publications by an authorized administrator of DigitalCommons@URI. For more information, please contact digitalcommons-group@uri.edu. 


\title{
Experiencing Research Firsthand: The "unClassroom" Experiential Learning Approach to Teaching Research Methods in an LIS Master's Program
}

\author{
By Lauren H. Mandel, PhD \\ University of Rhode Island, \\ Graduate School of Library and Information Studies \\ Email: lauren_mandel@uri.edu
}

\section{Preprint}

\begin{abstract}
Research methods education in LIS master's degree programs is facing several difficult questions: should a methods course be required, what content should be taught in that course, and what is the most effective mechanism for teaching that content. There is little consensus about what should be taught or how, but the American Library Association, LIS educators, and many practitioners seem to agree that research methods are vital skills for 21st century LIS practitioners. This paper reports on an experiential learning opportunity called the "unClassroom," which afforded LIS master's students the chance to complete a research project in one semester for an outside client (a statewide library consortium). The effectiveness of the unClassroom to teach research methods surpassed expectations and provides a model that may be of interest to other research methods educators in LIS master's programs.
\end{abstract}

\section{Keywords}

Research methods education, LIS curriculum, experiential learning, pedagogy

\section{Introduction}

There is an accepted need for research in LIS (Luo, 2011) and that research is required for the field to be a profession (Juznic \& Urbanija, 2003; McClure \& Bishop, 1989). While some may see research as the purview of LIS faculty (either in LIS schools or academic librarians), others note that research can be incorporated into field experience in public and special libraries too, such as in support of evidence-based librarianship, to demonstrate programmatic efficacy, and to secure funding (Berg, Hoffman, \& Dawson, 2009; Evans, Dresang, Campana, \& Feldman, 2013; Juznic \& Urbanija, 2003; Liebscher, 1998). In fact, we cannot rely on only LIS professors to produce research since LIS educators comprise a very small percentage of all LIS professionals (O'Connor \& Park, 2001, 2002; Park, 2003, 2004; Stephenson, 1990). Yet, there is limited research conducted by practitioners (Luo, 2011; Powell, Baker, \& Mika, 2002), at least partially due to "inadequate education in research methods" (Luo, 2011, p. 191).

This paper takes a look at the discussion surrounding research methods education in LIS and reports on an experiential learning opportunity that afforded LIS master's students the chance to complete a research project in one semester. That opportunity came via a 
pedagogical approach called the "unClassroom," in which a class partners with an outside client to complete a project (or several smaller projects) during the semester. The examples discussed here were partnerships with a statewide consortium and a state library agency to conduct research projects in a master's-level LIS research methods course via the unClassroom. The instructor had been initially apprehensive about undertaking a complete research project in one semester, but the results surpassed expectations and provide a model that may be of interest to other research methods educators in LIS master's programs.

\section{Background}

\section{Importance of research in LIS}

In addition to producing research, librarians are widespread consumers of research, both research in the field of LIS and research in other fields that is consumed in the course of providing reference and research services. The ability to critique research is important to be effective information providers (Juznic \& Urbanija, 2003). Therefore, librarians need to be knowledgeable about research methods (Park, 2003, 2004) and statistical analysis (Van Epps, 2012). One of the primary mechanisms by which librarians gain knowledge is through Master's degree programs in library and information studies (MLS, MLIS, etc.). Many courses in LIS Master's degree programs use research articles in required and recommended reading lists, but we may be expecting our students to read those research articles without sufficient background to fully comprehend them due to the lack of required research methods background (Park, 2003).

\section{Research practices of LIS practitioners}

LIS practitioners are consuming and producing research, even if it is a slower rate than might be desirable. Practitioners read research for their own edification (Juznic \& Urbanija, 2003; Luo, 2011; Powell et al., 2002) and to help patrons with their research (Luo, 2011). They apply research findings to their professional work (Juznic \& Urbanija, 2003), and sometimes conduct research projects to evaluate programs, assess users' needs, awareness, and perceptions, or for other reasons (Juznic \& Urbanija, 2003; Luo, 2011; Powell et al., 2002). A few are even publishing the results of their research (Powell et al., 2002).

There are numerous barriers for LIS practitioners to conduct research. The most commonly cited are lack of time and funding (Klobas \& Clyde, 2010; Koufogiannakis \& Crumley, 2006; Luo, 2011; Powell et al., 2002). Other barriers include lack of support (Koufogiannakis \& Crumley, 2006; Luo, 2011), lack of incentive (Luo, 2011), focus on practice over research in the LIS field (Luo, 2011; Powell et al., 2002), and poor communication between practitioners and researchers (Luo, 2011; McClure \& Bishop, 1989; Powell et al., 2002).

There is also the barrier of lack of education, skills, and experience (Klobas \& Clyde, 2010; Koufogiannakis \& Crumley, 2006; Perkins \& Helbig, 2008; Powell et al., 2002), which is the 
focus of this paper. This lack of education begins in the LIS curriculum and continues on the job, with librarians often not receiving research methods training in graduate LIS programs or professional positions (Koufogiannakis \& Crumley, 2006). Once librarians are on the job, this barrier grows because, even though most librarians are highly skilled in literature review, they "shudder at the thought of learning and utilizing research skills of expanding knowledge through hypothesis testing and quantitative methodology" (Perkins \& Helbig, 2008, p. 513).

\section{The place of research methods courses in LIS curricula}

Research methods education in LIS needs to be preparing both consumers and producers of research. The American Library Association (2009) has acknowledged this in identifying that Core Competency \#6 for librarians is research, including "fundamentals of quantitative and qualitative research methods" (6A), "central research findings and research literature of the field" (6B), and "principles and methods used to assess the actual and potential value of new research" (6C). The accreditation standards acknowledge this, but with emphasis on research consumption rather than research creation in standard II (COA, 2015). A survey of LIS practitioners found that $72.5 \%$ thought methods should be a required course in the MLIS curriculum (Luo, 2011). They identified numerous positive effects of the methods course: better understanding of LIS research literature and literature in other fields; ability to produce valid and reliable data on which to base decisions, identify problems in the workplace, and devise solutions for those problems; and skills in writing research papers for publication and grant applications.

Despite the fact that research is a Core Competency of Librarianship (ALA, 2009) and that many papers discuss the value of research methods as part of LIS master's degree programs, it is not required across the board. Data from the 2015 ALISE Statistical Report show that slightly more than half of MLS or equivalent degrees $(n=29 ; 53.7 \%)$ require a research methods course for graduation (Albertson, Spetka, \& Snow, 2015). This issue is not limited to the U.S. and Canada (where the ALA-accredited programs are located). Park (2004) found that only 6 of 20 LIS schools in Korea required a methods course. Data show that 11 of the 13 schools ranked in the top 10 in the 2009 US News report offered at least one methods course (Luo, 2010), but only three actually required a research methods or statistics class for graduation (Van Epps, 2012), leading Van Epps to say that LIS schools are "falling down on the job" of preparing competent research consumers (p. x).

\section{Pedagogical approaches to teaching research methods in LIS}

LIS Master's degree programs often offer survey courses on research methods, which 0 'Connor and Park note is fine for research consumers but insufficient to produce research creators (2001). There is loose definition of what a research methods course is (Park, 2003), with some teaching quantitative and qualitative methods to others teaching only survey method. Practitioners are more likely to say their MLS program prepared them to read and understand published research than to conduct research (Powell et al., 2002). There is also minimal coverage of statistical analysis (Van Epps, 2012), which is 
problematic for both producers and consumers of research since consumers need some knowledge of statistics to understand research papers.

The literature includes discussion about a need to focus on writing research proposals, grants, and papers for publication, which methods to cover, whether to focus on quantitative, qualitative, or both types of measures, and how much (if any) statistics should be taught. Perkins and Helbig surveyed LIS authors (2008) about which topics from research methods courses they perceived to be most useful to their work. The most useful topics were (from highest to lowest): literature critique, research proposal, scholarly publication process, interpreting results/discussion, data collection, qualitative methods/analysis, oral presentation, application of other research to LIS, and questionnaires. Except for data collection and analysis, this mirrors what is taught in methods courses, with common assignments including critique of published research, critique of research proposals, proposal writing, and survey method (Luo, 2011; Park, 2004; Perkins \& Helbig, 2008; Smith \& Adams, 1992; Stephenson, 1990).

One of the problems with research methods courses is that "many students who do take a basic course in research methods often cannot see the practical applicability of the course" (Berg et al., 2009, p. 593). Perhaps if the methods course were designed around practical applications, those students might better be able to see the value of the course to their professional future. Such a course might also be more effective at "conveying enthusiasm or commitment to research" (Perkins \& Helbig, 2008, p. 514). But how to do that remains uncertain. There is a recognized need to consider new pedagogical approaches to teaching research methods in LIS (Dilevko, 2000; Juznic \& Urbanija, 2003; Koufogiannakis \& Crumley, 2006) with suggestions to focus on triangulation (Liebscher, 1998), having multiple sections of methods courses to increase depth of coverage in each section (Luo, 2011), and incorporating research methods into other courses (Luo, 2011). LIS programs are largely comprised of students from various backgrounds, many of whom lack any research or statistics background and have anxiety about learning these subjects (Dilevko, 2000). LIS educators need to explain what research is, why it is done, the purpose of research, and how to use research (Juznic \& Urbanija, 2003) so students can see the impact of the research methods course on their professional lives (Koufogiannakis \& Crumley, 2006).

\section{Experiential learning as an approach to teaching research methods in LIS}

Experiential learning, "learning by doing” (Bossaller, 2016, p. 35), is a focus in LIS. A search of Library, Information Science \& Technology Abstracts for the subject term "experiential learning" returned 164 peer-reviewed articles from 1997 to 2016, a 20-year span. Over one-third of these articles ( $n=58 ; 35.3 \%)$ were from the last five years (2012-2016). Bossaller explains Dewey's experiential learning model as a pedagogical technique that "allows students to apply the scientific method in the classroom" (2016, p. 37) and Kolb's expansion of this to a pedagogical model "in which students work with the community" (p. 37). This makes experiential learning well suited for teaching research methods since it encourages partnership with the community to apply scientific research methods. 
Several librarians (Berg et al., 2009) and LIS educators (Evans et al., 2013) have called for hands-on experiential opportunities for LIS Master's students to practice research, from the beginning of a research project through publication of findings. Liebscher said such experience is necessary because they "cannot learn to do or to evaluate research from the literature alone" (1998, p. 669). This sentiment was echoed by practitioners who suggested more hands-on practice conducting research, incorporation of more examples of how practitioners conduct and consume research, and greater focus on applying research to solving practical problems in the field (Luo, 2011). Others suggested hands-on research experience as a way to increase interest in and knowledge of research methods among practitioners (Powell et al., 2002).

Such hands-on experience is rare, which means that "many programs are losing their 'golden opportunity' to convince students of the intellectual and personal satisfaction that can be associated with performing research" (Stephenson, 1990, p. 58). There are some research methods courses in LIS master's degree programs that do require students to complete a research project, but many of these employ only survey method and few use any qualitative methods (Evans et al., 2013). Research in Action is a 2-quarter course at the University of Washington iSchool. In the first quarter, students learn about methods, and in the second quarter, they collect, code, and analyze data. Assignments include completion of human subjects training, observations of storytimes for practice to increase reliability, and later observation to collect, code, and analyze data. This project worked due to partnerships with organizations outside the university, supported by a grant.

\section{The unClassroom experience: An example of experiential research methods education}

\section{Background of the unClassroom}

The University of Rhode Island (URI) Graduate School of Library and Information Studies (GSLIS) resides within the Harrington School of Communication and Media. A new concept in experiential learning was proposed in the Harrington School in 2014, the unClassroom. In an unClassroom, "Students make it real with their work on a substantive real-world project for a partner from a business, non-profit, social service, or other organization" (Romanelli, 2014, para. 1). The first unClassroom in GSLIS was an iteration of LSC 517: Community Relations for Libraries in Fall 2014. In that opportunity, students worked in teams to complete needs assessments for branches of the Cranston Public Library (CPL). Because that unClassroom was successful, the director of CPL and the director of Ocean State Libraries (OSL), a statewide public library consortium, approached GSLIS faculty in the fall of 2015 about collaborating on another unClassroom.

They were thinking of another iteration of LSC 517, but the faculty member teaching that course in Spring 2016 was also scheduled to teach LSC 557: Document, Assess, Evaluate, the required GSLIS research methods course. This faculty member had taught LSC 557 several times before, and every time, there was always at least one student who complained that the course had no place in the core curriculum because libraries don't do research. So the faculty member proposed to OSL that the unClassroom be for LSC 557. It 
made sense to both parties that a research project belonged in LSC 557, and they began planning the course.

OSL was interested in finding out about consortial services offered in New England and Long Island (their regional peer group), as well as the views of Rhode Island public libraries on their satisfaction with the consortial services they were receiving. After some back and forth over email, the professor drafted a proposal for a multi-method research project that could be completed in one semester. OSL reviewed the proposal, concurred with the project, and agreed to attend some course sessions to answer student questions and view presentation of research findings. Consultation with the URI Office for Research Integrity confirmed that research conducted within a course, for the course, and not for publication did not need to go through IRB review.

\section{Prior iterations of LSC 557}

The Spring 2016 unClassroom was the sixth time this instructor taught LSC 557. The first iteration (Fall 2012) followed the format previously in use at GSLIS for teaching research methods, which relied heavily on students' development of a research proposal. The research proposal served as both a way to measure students' achievement of course learning outcomes such as "Identify the steps for developing a research proposal; write research questions; define concepts and operationalize variables; review literature; and detail a research design including method and sample strategies" and as the major paper requirement. Until Spring 2017, URI required non-thesis master's programs to designate one course that fulfills the major paper requirement, and for GSLIS, that course has been LSC 557. After the Fall 2012 iteration, the professor decided to modify the research proposal from a general proposal to a proposal for an Institute of Museum and Library Services National Leadership Grant in the research category. This was done to quell student complaints about seemingly arbitrary formatting guidelines and to provide students the dual learning opportunity of writing a research proposal and a grant proposal. That assignment was used in Spring, Summer, and Fall 2013, and Spring 2014. The professor did not teach LSC 557 from Summer 2014 until the unClassroom iteration in Spring 2016.

There is nothing wrong with the research proposal as a major assignment in a research methods course in the LIS curriculum. In all five semesters that this instructor taught LSC 557 using the research proposal, the average grade in the class for the final proposal assignment was over $90 \%$, and, several students have commented on its value after working in the field. One applied her experience writing a grant proposal in LSC 557 to writing a successful grant application for her library. But, the proposal does have the limitation that students do not get to collect data, analyze data, or present research findings. This instructor had long been interested in devising a way for students to complete an entire research project, but that is a difficult challenge to achieve in one semester. The opportunity presented by OSL made it possible for the instructor to tackle this challenge head-on. 
URI operates on a 13-week spring semester, so the course had to be designed in such a way that students could develop data collection plans and instruments, collect data, analyze data, and present findings, all within 13 weeks. Previously, the instructor had been teaching this course with bi-weekly synchronous sessions, sometimes face-to-face and sometimes online in the Sakai Meetings tool or WebEx. The class was set up in two-week pairs: in Week A, students read, viewed an online lesson, and sometimes took a quiz or participated in discussion board and Week B was an active learning week with in-class exercises in the synchronous class session. Table 1 shows the weekly structure for the Spring 2014 iteration of LSC 557.

Table 1: Weekly structure for classic iteration of LSC 557 (research methods course)

\begin{tabular}{|c|c|c|}
\hline Week & Type of week & Topic and activities \\
\hline 1 & Reading & $\begin{array}{l}\text { Introduction to Research and Research Ethics } \\
\text { - Readings } \\
\text { - Lesson }\end{array}$ \\
\hline 2 & Active learning & $\begin{array}{l}\text { Introduction to Research and Research Ethics } \\
\text { - Face-to-face class } \\
\text { - In-class exercise on research ethics }\end{array}$ \\
\hline 3 & Reading & $\begin{array}{l}\text { Reading and Writing Research } \\
\text { - Readings } \\
\text { - Lesson } \\
\text { - Identification of topic \& draft research question } \\
\text { assignment }\end{array}$ \\
\hline 4 & Active learning & $\begin{array}{l}\text { Reading and Writing Research } \\
\text { - Face-to-face class } \\
\text { - In-class exercise on critiquing research } \\
\end{array}$ \\
\hline 5 & Reading & $\begin{array}{l}\text { Research Purpose and Design } \\
\text { - Readings } \\
\text { - Lesson } \\
\text { - Article critique } 1 \text { assignment } \\
\end{array}$ \\
\hline 6 & Active learning & $\begin{array}{l}\text { Research Purpose and Design } \\
\text { - Face-to-face class } \\
\text { - In-class exercise on evaluation research } \\
\text { - Statement of need section due }\end{array}$ \\
\hline 7 & Reading & $\begin{array}{l}\text { Measurement, Scales, and Samples } \\
\text { - Readings } \\
\text { - Lesson }\end{array}$ \\
\hline 8 & $\begin{array}{l}\text { Reading \& } \\
\text { Active learning }\end{array}$ & $\begin{array}{l}\text { Measurement, Scales, and Samples } \\
\text { - } \quad \text { Readings and lesson on experiments and surveys } \\
\text { - } \text { Face-to-face class } \\
\text { - In-class exercise on measurement and scales } \\
\text { - Impact section due }\end{array}$ \\
\hline 9 & Active learning & Experiments and Surveys \\
\hline
\end{tabular}




\begin{tabular}{|c|c|c|}
\hline & & $\begin{array}{l}\text { - Face-to-face class } \\
\text { - In-class exercise on experiments and surveys }\end{array}$ \\
\hline 10 & Reading & $\begin{array}{l}\text { Qualitative Field Research and Unobtrusive Research } \\
\text { - Readings } \\
\text { - Lesson } \\
\text { - Article critique } 2 \text { assignment }\end{array}$ \\
\hline 11 & Active learning & $\begin{array}{l}\text { Qualitative Field Research and Unobtrusive Research } \\
\text { - Face-to-face class } \\
\text { - In-class exercise on interviews, focus groups, \& } \\
\text { - observation } \\
\text { - Project design section due } \\
\end{array}$ \\
\hline 12 & Reading & $\begin{array}{l}\text { Data Analysis } \\
\qquad \quad \text { Readings } \\
\cdot \quad \text { Lesson }\end{array}$ \\
\hline 13 & Active learning & $\begin{array}{l}\text { Presenting Research } \\
\text { - Face-to-face class } \\
\text { - In-class presentations } \\
\text { - } \quad \text { Final proposal assignment }\end{array}$ \\
\hline
\end{tabular}

\section{Course structure for unClassroom iteration of LSC 557}

One of the first considerations in designing the unClassroom version of LSC 557 was how to divide up the workload on the research project to get it all done in one semester. The research project necessitated teamwork to complete it all within 13 weeks, and teamwork seemed a useful pedagogical tool since research is often completed in teams. The first research project (Spring 2016) with OSL was designed to use three data collection methods (survey of public libraries, interviews with consortia directors, and content analysis of consortia documents) and collect data in New England and Long Island. Each team was assigned to one region and was responsible for the collection and analysis of data from that region. The second project (Spring 2017) was a partnership with the RI Office of Library and Information Services (OLIS), the state library agency, to evaluate the state's administration of the annual public library survey. This was also a multi-method project, using telephone survey of state data coordinators, interviews with library directors who complete the survey for their library, and secondary analysis of the IMLS public library dataset. Each team was assigned a region of the country for the telephone surveys and secondary analysis and a region of the state for interviews.

But how could the class work cooperatively to design the data collection plans and instruments? In Spring 2016, the instructor decided on a jigsaw approach. She created three working groups, one for each method, and those working groups would only exist for the first part of the course to develop the data collection plans and instruments. Since there were 15 students, it worked out mathematically to have 5 students per working group, with each student in the working group representing one of the regional teams (see Figure 1). 


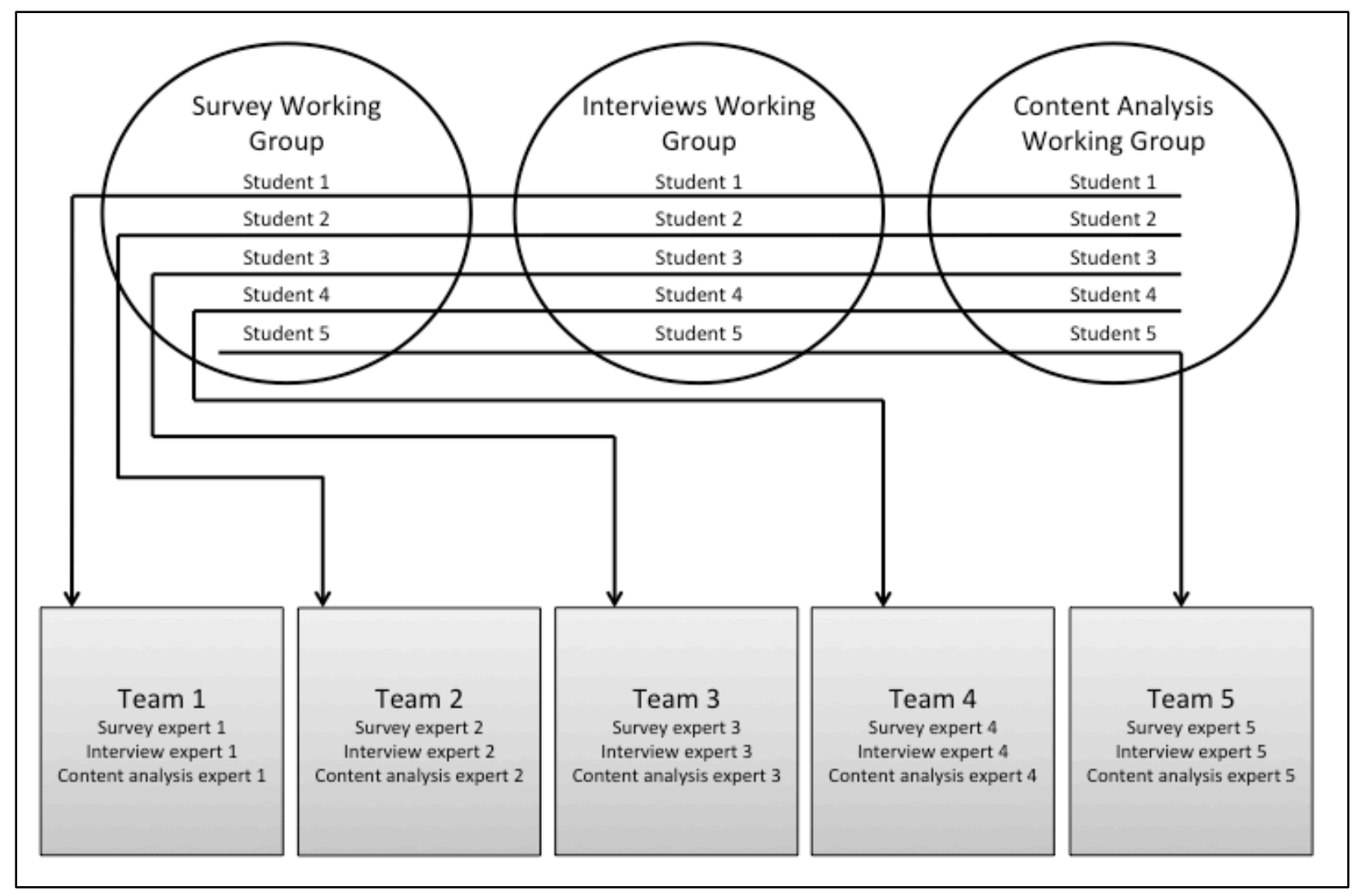

Figure 1. Jigsaw approach to working groups and teams.

As the figure shows, each student was considered his or her team's "expert" in one method, based on working group assignment. Students were assigned to working groups based on their stated preference of method. Teams were created after working groups to ensure that each team had one "expert" in each method. The jigsaw approach worked well in the Spring 2016 unClassroom given the good luck in getting 15 students enrolled in the course (in the second iteration, there were 21 students divided into three working groups and six teams). In the beginning, students were a little confused about being in both a team and a working group, but by the fourth week, everyone understood exactly how the system was working to allow the class to complete an entire research project in one semester. The Spring 2017 syllabus included Figure 1 to illustrate the system for students, but some were still confused at the beginning of the course. The instructor is considering trying a different arrangement for the next iteration in which students will work in the same team from start to finish, with each team assigned to its own, smaller research project.

The next step was organizing the course structure so all critical content would be covered and students would have the time to design and complete the research project and a major paper, since that still had to be included in accordance with URI rules. Both Spring 2016 and 2017 unClassrooms, like prior iterations of LSC 557, operated on a bi-weekly synchronous class meeting system, where synchronous weeks alternated with asynchronous weeks. Instead of a reading week and an active learning week, all of the 
readings and lessons were completed asynchronously, and synchronous sessions were dedicated to the research project and article critiques. Synchronous sessions were held in WebEx Training Center, which affords the option of breakout rooms. Figure 2 shows the course structure for the 2016 unClassroom iteration of LSC 557.

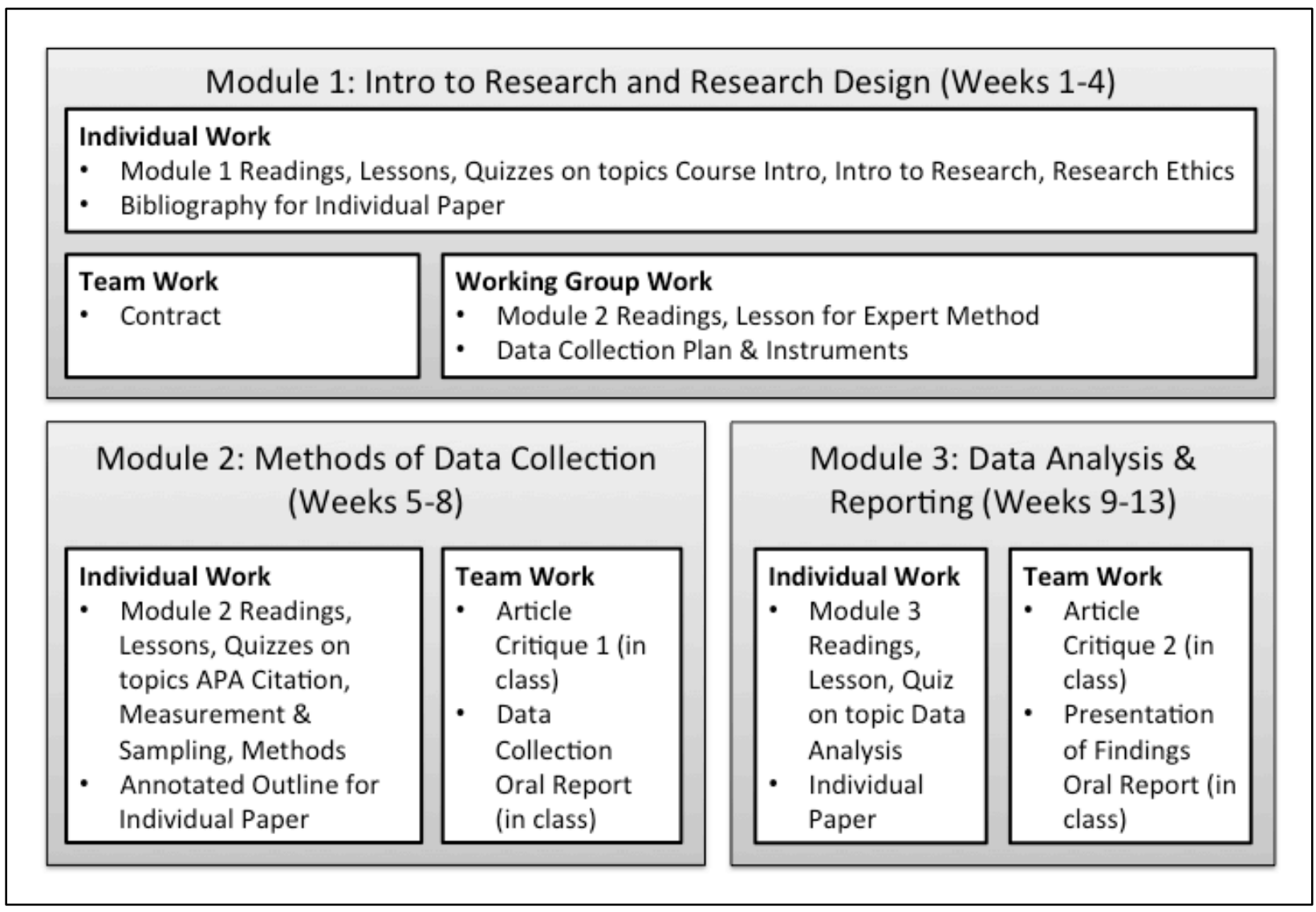

Figure 2. Course structure for unClassroom iteration of LSC 557 (research methods course)

A major challenge was that students needed to learn about introductory research concepts and research ethics concurrently with their working group's method. To that end, module 2 (which encompassed lessons on measurement, sampling, and individual data collection methods) was open from the first day of the course so that working groups could review the readings and lessons on their "expert" methods from the beginning. This meant the up front workload for students was very heavy; they needed to learn about what research is, the different purposes of research, research design, research ethics, measurement, sampling, and one method all by the end of the fourth week of the semester. While that was a heavy load, all the students in both Spring 2016 and 2017 unClassrooms committed to the course and the challenge, and all succeeded in accomplishing that goal.

The schedule was the same in Spring 2016 and 2017. The first class session was an introduction and overview session held without partners so that students felt free to ask anything they wanted without potentially feeling foolish in front of OSL and OLIS staff. The 
second class was held in week 3 with our partners, and students had the opportunity to ask them questions to help in designing data collection plans and instruments. Working groups presented their draft data collection plans and instruments in the third class session in week 5 (Spring 2016 without the partner, Spring 2017 with the partner), which were edited and agreed upon together in the class. The fourth and sixth class sessions were used for in-class team exercises on article critiques (done using the breakout rooms). The partners joined us for the fifth class session in week 8 during which teams reported on their data collection activities and the final class session in which teams presented their findings to the instructor, class, and partners. Throughout the semester, the instructor maintained a document recording the research design, starting from the background and research questions, adding the data collection plans and instruments, and then the results of data collection. Updated versions of this document were provided to students and the partners throughout the semester.

The assignments previously used by the instructor in LSC 557 were two article critiques, the components of a research proposal with a final proposal and presentation, in-class exercises on research techniques, and an assortment of quizzes and discussion board posts. In the unClassroom approach, the research project replaced the proposal and all of its component assignments, the article critiques were done as teamwork in class (so as not to overburden the students with outside assignments), quizzes were used to assess students' knowledge on basic research concepts, and a final paper was assigned where students had to explain the use of a specific method in LIS. Students were encouraged to write these papers on their "expert" method from the working groups.

\section{Findings regarding the use of the unClassroom for teaching research methods in an LIS master's degree program}

\section{Challenge in coordinating research methods in the unClassroom}

There were several challenges to designing and running LSC 557 as an unClassroom. The biggest one was already mentioned - completing an entire research project in one semester. This was aided by the fact that the URI IRB doesn't review research projects in courses that are purely for the sake of learning and not to disseminate research findings. It was also aided by the instructor's prior experience teaching this course and conducting research. The instructor was able to map out a strategy by which the course could frontload the introductory research concepts plus one method during the first four weeks so that working groups could develop data collection plans and instruments within the first month of the class, allowing time for data collection and analysis by the end of the semester. Another mechanism to combat this time limit would be to reduce the scope of the research project. Both projects used three methods of data collection, analysis of data collected from all three methods, plus triangulation of data. Another instructor might consider running a single method or two-method project, rather than a three-method project.

As with any pedagogical choice, there was a trade-off with the unClassroom in that students didn't get practice writing a grant proposal. They also did not get the opportunity 
to choose their own research topic or write the research questions. Also, each student really only became an expert in one of the three methods, the one from their working group. Some of these limitations were offset by what students did learn and experience: data collection, data analysis, reporting of findings, and conducting research as part of a team on demand for an outside agency. While students did become experts in only one method, they gained experience in all three since they all collected data using all three methods, and conducted triangulation as part of their team. Also, they all participated in class discussion and finalization of the data collection plans and instruments so had some involvement in the development and administration of all three methods.

One of the issues that emerged toward the end of the Spring 2016 semester was consistency with which the teams reported their findings. In Spring 2017, more specific instructions were given for what to include in the final report and that it needed to be both a written document that could easily be given to the partner and an oral report in class. Another option would be to format the research project document with sections for the working groups and teams to fill in as the project progresses, so it goes from being a design document to a final report for the client. The way it worked in Spring 2016, the instructor began the document with background, research purpose, and research questions. Then, after the teams finalized the data collection plans, the instructor added those. But when it came time to add the findings, it turned out to be very difficult because teams had not been asked to report uniformly on things like response rate. Instead, teams were given wide latitude in how they presented their findings and shared their data. This collation process was facilitated by the more detailed instructions given in Spring 2017.

Because the research projects were completed for a course and therefore deemed by the URI IRB not subject to human subjects review, the students and instructor cannot publish the findings of the research projects. The only ways to overcome this would be to lengthen the course beyond one semester or for the instructor to design the entire research project, including all data collection instruments. The instructor could then submit the project to the IRB in the preceding semester, have the students take the IRB training in the beginning of the course, and submit a study modification to add all the students as researchers on the project. But this would take away the students' opportunity to develop the data collection plans and instruments, a key component of the course.

\section{Student achievement of learning objectives}

The course learning objectives were modified in different iterations of the course based on changes to departmental learning outcomes and the objectives that could be measured with different assignments. The Spring 2016 and Spring 2017 unClassroom iterations were designed around the following learning objectives:

1. Define and differentiate quantitative and qualitative research.

2. Describe ethics of social research and consider the balance of risks and benefits related to social science research.

3. Recognize, describe, and apply social science research methods.

4. Explain how research is conducted in library and information studies. 
5. Identify, locate, summarize, evaluate, and apply LIS literature to a research problem.

6. Develop data collection instruments and collect and analyze data.

7. Demonstrate effective communication skills.

8. Support and evaluate the work of colleagues.

Learning objective 6 could not have been achieved using the research proposal since the proposal assignment stops prior to data collection. In the unClassroom approach, students experienced the challenges inherent in data collection. A student in 2012 once posted a critique to the discussion board about the low response rate in a published survey that had a response rate of 51\%. Students who actually conducted a survey in Spring 2016 would likely be more understanding given that all Spring 2016 teams reported response rates under $50 \%$. This was an eye-opening experience for the students regarding the challenges in recruiting participants and generating a high response rate.

Students also had to analyze both quantitative and qualitative data. In both Spring 2016 and Spring 2017, students expressed surprise at how hard it was to reconcile the data collection and analysis plans with the reality of the data. Because they had never done research before, their plans for analysis were based on assumptions of how the data would look, but when they saw the actual data, the plans were not always feasible. They also had to determine how to present their findings to the class, professor, and client. One spring 2016 team said they had to weigh which data was most important to include in the presentation and what could be left out, noting that by overcoming such challenges, they gained substantial knowledge. This is another example of an experience that students could not have if their research project ended at the proposal stage. In Spring 2017, the teams got very ambitious with data analysis; one team even ran multiple linear regression in $\mathrm{R}$.

Learning objectives 2 and 3 were strengthened by the unClassroom approach. In prior iterations, students learned about research ethics in theory and they planned for ethical research in their research proposals, for example creating a plan to maintain confidentiality during data collection. In the unClassroom, they were confronted with ethical issues they had to resolve. Students actually had to reassure participants that their data would be confidential and clean interview data to ensure participants' identities were unknown prior to submitting their data to be shared with the partner. Spring 2016 teams reported challenges in scheduling interviews with consortia directors who were both very busy and concerned about the privacy of their organizations' documents. In Spring 2017, a discussion ensued about how to report interviewees' words without violating their confidentiality, something that never came up in iterations of this course using the research proposal.

The same is true for learning objective 3; in the unClassroom approach, students were able to achieve the learning objective in practice rather than theory. As researchers know, sometimes a method is selected that is not ultimately effective in addressing the research question or it can turn out that survey and interview questions were less clear than researchers had thought. When the class ended with the proposal, students did not get to experience those outcomes. With the unClassroom approach, they do. For example, the 
Spring 2017 teams reported some interviewees were confused by some of the interview questions and some of the questions were redundant or could have been ordered more logically. They suggested future research should test the interview script on someone other than members of the research team to test for issues like this. These students experienced a problem with a data collection method, analyzed that problem, and identified a possible solution that could be tested with future research. None of that learning would be possible with a research proposal.

\section{Instructor availability to students}

Going into an unClassroom research methods course, the instructor knows that the project might be a huge success, it might be a failure, or it might land somewhere in between. The instructor must commit to providing intensive assistance to students, especially in the beginning of the course while they are concurrently learning the basics of research and developing data collection plans and instruments and at the end of the course while they are simultaneously learning about and conducting data analysis.

A major factor in the success of this course was the availability of the instructor to the students throughout the semester and her responsiveness to students' needs in a new approach to a difficult course. In both Spring 2016 and Spring 2017, the instructor met with working groups during module 1 to brainstorm on data collection plans and instruments and reviewed drafts of both data collection plans and instruments. There was less need for this hands-on instruction during module 2 while teams were actively collecting data, but the instructor was still available and responsive to inquiries about issues with sampling, data collection, and response rates. In module 3 , there was considerable need for instructor availability to assist teams in data analysis. Data analysis had previously been given very little coverage in LSC 557 since students did not actually analyze data. For the Spring 2016 iteration of the course, the instructor developed a detailed online lesson with examples of how to calculate descriptive statistics, and which statistics to use based on the measurement level of different variables. The instructor also met with teams in both Spring 2016 and Spring 2017 to discuss data analysis strategies and review drafts of tables, charts, and presentations of findings.

The instructor presented at the October 2016 New England Library Association (NELA) Conference with three students from the Spring 2016 iteration about the course. One of the students noted that the course likely would not have been as successful if the instructor had not been so available, willing, and able to assist students through the entire research process (Mandel, Estrella, Taft, \& Vaandering, 2016). Results from the IDEA student evaluation of teaching survey show an increased score in the Establishing Rapport category, "Encouraged student-faculty interaction outside of class (office visits, phone calls, e-mails, etc.)" for Spring 2016. This score increased from 4.1, with 69\% of students rating 4 (frequently) or 5 (almost always) in Fall 2012 to 4.8, with $100 \%$ of students rating 4 or 5 , in Spring 2016. One of the suggestions from practitioners about improving research methods courses in LIS programs is to use someone who is an "engaging instructor" (Luo, 2011, p. 197). This unClassroom experience supports the need for an instructor for 
research methods who is not only engaging, but also engaged in the course and with the students.

\section{Students see relevance and value of research methods to LIS and are prepared to consume and produce research}

While the challenges to using the unClassroom format to teach research methods might seem daunting, the benefits are significant. How many of us have had to listen to students complain about why research methods is required and how it is irrelevant to their professional lives because no one in libraries does research? That question never came up in the unClassroom iterations of LSC 557. By doing a project for a library organization because the organization needed a research project to be conducted but lacked staff with the skills and experience to do it, that question was answered from the beginning. This benefit addresses the concern that "many students who do take a basic course in research methods often cannot see the practical applicability of the course" (Berg et al., 2009, p. 593). In Spring 2017, one student began her final paper by saying, "Through research, librarians are able to stay relevant and adjust to the ever evolving world around them. Research allows librarians to meet their patrons' needs as well as find ways to attract and support an even larger community" (White, 2017, p. 1). This student clearly sees how research methods are applicable to her future career as a school librarian.

Beyond the benefits of quieting the complaints about research methods and students learning more skills, the unClassroom experience was one that resonated with students. They actually liked learning about research methods and enjoyed the course. One student said on the IDEA survey, "The real-world application of concepts increased my understanding, and has made me a better researcher, and interpreter of others' research." Several students commented on the positive experience the course had with regard to networking. Having to contact librarians, library directors, and library consortia both took students out of their comfort zone and increased their interactions with working professionals. In the NELA presentation (Mandel et al., 2016), one student said this was an "example of networking and professional interviewing" that was a "very positive experience" (Slide 7). Another student shared that the unClassroom gave her and her classmates "a better understanding of the importance of methodology to social science research," "a firmer grasp on what to expect when conducting original research," and "preparation to enter the professional field as better readers and communicators of LIS research" (Slide 12). At the most recent departmental annual gathering in April 2017, two students who had been in the Spring 2016 class approached the professor to express how much they had learned from the unClassroom version of LSC 557.

One of the problems identified in the literature is that LIS students are not prepared to conduct research after graduating from Master's degree programs (Koufogiannakis \& Crumley, 2006). This is a huge benefit of the unClassroom approach to teaching research methods. In this course, students learned by doing; they designed data collection plans and instruments for three different methods, collected and analyzed data, and reported findings. These are all skills that cannot be taught with the research proposal alone. 


\section{Partner benefits from skills and expertise they lack}

There were also benefits from the partnership with outside organizations that transcend the issue of teaching research methods in LIS curricula. By partnering with OSL and OLIS, the partners gained data and knowledge they could not have gotten on their own due to lack of time, personnel, and skills. In this case, that data and knowledge was from a research project, but similar benefits could be seen from partnering in many other types of LIS courses. A prior unClassroom (discussed earlier) provided the Cranston Public Library with needs assessment data for their branch libraries, and the possibilities are fairly limitless. For example an unClassroom could enable students to develop and host programs in libraries, affording students hands-on experience with programming and expanding libraries' program offerings beyond what they could offer given their staffing levels. Partnering with OSL, the statewide consortium of all public libraries in RI, and OLIS, the state library agency, also raised students' work ethic because no one wanted to be seen as the slacker group in front of either partner. There was strong commitment from the students to provide a quality product to the partner at the end of the course.

\section{Conclusions}

The ability of library and information professionals to responsibly consume and competently produce research is critical to the growth of the field, and to the way other disciplines view LIS. That ability is limited when LIS curricula do not emphasize research methods as a critical skill for their graduates. It cannot be surprising to us that LIS professionals do not do research when they are not taught how to do it in graduate school. One way to combat this is to require research methods. But simply requiring the course is not enough; it is already established in the literature that many graduates are not applying what they learned in research methods courses to their professional work. We need to ask ourselves why this is so. Sure, there is a dearth of funding, both internal and external, in support of research. This is especially pronounced in school and public libraries, where there is not only no funding for research, but there is also no time for research and no incentive for librarians to conduct or publish research (such as the demands of tenure that push many academic librarians to conduct research). As LIS educators, increasing funding streams for research is beyond our purview, but considering new pedagogical models for how to teach research methods is part of our job.

There are already discussions in the literature about how best to teach research methods in order to educate LIS students to become consumers and producers of research. Much of this discussion focuses on questions of which methodologies should be taught and whether statistics should be covered in the LIS curriculum. A larger question is how research methods (whichever method and whether with statistics or not) can be taught to spark students' interest in research, help them see the relevance and importance of research to their future careers, and prepare them to conduct and publish research once they are working members of the profession. This paper discusses one such mechanism, the unClassroom. In the unClassroom, students, the instructor, and an outside client work together to produce something that none could do alone. When used to teach research methods, the unClassroom can result in a completed research project, something that is 
useful for the client as they review their services and programs, something that gives students hands on experience that cannot be gained through completion of a research proposal, and something that gives the instructor satisfaction in knowing what can be accomplished when teams work together toward a common research goal.

\section{Acknowledgements}

The author gratefully acknowledges the support of Ocean State Libraries and the Rhode Island Office of Library and Information Services, as well as the dedication and hard work of the students at URI GSLIS.

\section{References}

Albertson, D., Spetka, K., \& Snow, K. (Eds.). (2015). Library and information science education statistical report 2015. Seattle, WA: Association for Library and Information Science Education. Retrieved from https://ali.memberclicks.net/assets/documents/statistical_reports/2015/alise_201 5_statistical_report.pdf

American Library Association. (2009). ALA's core competences of librarianship. Chicago, IL: American Library Association. Retrieved from http://www.ala.org/educationcareers/sites/ala.org.educationcareers/files/content /careers/corecomp/corecompetences/finalcorecompstat09.pdf

Berg, S. A., Hoffman, K., \& Dawson, D. (2009). Perspectives on...integrating research into LIS field experiences in academic libraries. The Journal of Academic Librarianship, 35(6), 591-598.

Bossaller, J. (2016). Service learning as innovative pedagogy in online learning. Education for Information, 32, 35-53. doi:10.3233/EFI-150962

Committee on Accreditation of the American Library Association. (2015). Standards for accreditation of master's programs in library and information studies. Chicago, IL: American Library Association. Retrieved from http://www.ala.org/accreditedprograms/sites/ala.org.accreditedprograms/files/co ntent/standards/Standards_2015_adopted_02-02-15.pdf

Dilevko, J. (2000). A new approach to teaching research methods courses in LIS programs. Journal of Education for Library and Information Science, 41(4), 307-329.

Evans, A., Dresang, E., Campana, K., \& Feldman, E. (2013). Research in action: Taking classroom learning to the field. Journal of Education for Library and Information Science, 54(3), 244-252.

Juznik, P., \& Urbanika, J. (2003). Developing research skills in library and information science studies. Library Management, 24(6/7), 324-331. doi:10.1108/01435120310486048

Klobas, J. E., \& Clyde, L. A. (2010). Beliefs, attitudes and perceptions about research and practice in a professional field. Library and Information Science Research, 32(4), 23745. doi:10.1016/j.lisr.2010.07.004

Koufogiannakis, D., \& Crumley, E. (2006). Research in librarianship: Issues to consider. Library Hi Tech, 24(3), 324-340. doi:10.1108/07378830610692109

Liebscher, P. (1998). Quantity with quality? Teaching quantitative and qualitative methods in and LIS Master's program. Library Trends, 46(4), 668-680. 
Luo, L. (2011). Fusing research into practice: The role of research methods education. Library and Information Science Research, 33(3), 191-201. doi:10.1016/j.lisr.2010.12.001

Mandel, L. H., Estrella, D., Taft, A., \& Vaandering, A. (2016, October). Grad students + libraries = successful partnerships. Paper session presented at the New England Library Association Conference, Danvers, MA.

McClure, C. R., \& Bishop, A. (1989). The status of research in library/information science: Guarded optimism. College \& Research Libraries, 50(2), 127-143. doi:10.5860/crl_50_02_127

O'Connor, D., \& Park, S. (2001). Crisis in LIS research capacity. Library and Information Science Research, 23(2), 103-106.

O'Connor, D., \& Park, S. (2002). On my mind: Research methods as essential knowledge. American Libraries, 33(1), 50.

Park, S. (2003). Research methods as a core competency. Journal of Education for Library and Information Science, 44(1), 17-25.

Park, S. (2004). The study of research methods in LIS education: Issues in Korean and U.S. universities. Library and Information Science Research, 26(4), 501-510. doi:10.1016/j.lisr.2004.04.009

Perkins, G. H., \& Helbig, T. L. (2008). The value of LIS schools' research topics to library authors' professional work. The Journal of Academic Librarianship, 34(6), 513-519.

Powell, R. R., Baker, L. M., \& Mika, J. J. (2002). Library and information science practitioners and research. Library and Information Science Research, 24(1), 49-72. doi:10.1016/S0740-8188(01)00104-9

Romanelli, F. (2014). Introducing the unClassroom. Retrieved from http://harrington.uri.edu/news/introducing-the-unclassroom/

Smith, N. M., \& Adams, I. (1992). Characteristics of research courses in library schools. Journal of Education for Library and Information Science, 33(1), 75-78.

Stephenson, M. S. (1990). Teaching research methods in library and information studies programs. Journal of Education for Library and Information Science, 31(1), 49-65.

Van Epps, A. S. (2012). Librarians and statistics: Thoughts on a tentative relationship. Practical Academic Librarianship: The International Journal of the SLA Academic Division, 2(1), i-xiii.

White, N. (2017). Final paper. Unpublished manuscript, Graduate School of Library and Information Studies, University of Rhode Island, Kingston, RI. 